\title{
Skull Base Meningioma
}

National Cancer Institute

\section{Source}

National Cancer Institute. Skull Base Meningioma. NCI Thesaurus. Code C5272.

A meningioma that arises from the skull base. 